\title{
ПРОБЛЕМА ФОРМУВАННЯ IНФОРМАТИЧНИХ КОМПЕТЕНТНОСТЕЙ У СТАРШОКЛАСНИКІВ ІЗ ПСИХОФІЗИЧНИМИ ПОРУШЕННЯМИ
}

Ірина Татьянчикова, ДВНЗ «Донбаський державний педагогічний університет», м. Слов'янськ, Україна, i.tatyanchikova@gmail.com;

Тамара Сахно, ДВНЗ «Донбаський державний педагогічний університет», м. Слов'янськ, Україна, t.s.sahno@gmail.com

Розглянуто проблему фрормування інформатичних компетентностей у старшокласників із психофрізичними порушеннями. Представлено аналіз сучасних психолого-педагогічних досліджень щодо доцільності та ефективності використання комп'ютерних технологій у навчально-виховному процесі спеціальних навчальних закладів. Установлено, що використання інформаційних технологій дає можливість модернізувати й підвищити якість навчання, а також інтерес учнів до оволодіння базовими знаннями, що впливає на формування в них інформаційно-комунікаційних компетентностей. Звернено увагу на корекційну спрямованість використання комп'ютерних технологій у процесі опанування учнями навчального матеріалу, оскільки цей процес відбувається у них зі значними труднощами, що зумовлено їхніми обмеженими можливостями. Установлено, що без наявності певних знань у галузі інформатики таким учням неможливо пристосуватись до життя у суспільному просторі після закінчення школи. Доведено, що стан теоретичного й практичного розв'язання цієї проблеми у спеціальній педагогіці не задовільняє сучасні суспільні потреби, що вказує на актуальність та затребуваність порушених питань. У статті обґрунтовано необхідність визначення педагогічних технологій формування інформатичних компетентностей в учнів старших класів спеціальної загальноосвітньої школи.

Ключові слова: інсорматична компетентність, інформаційно-комунікаційні технології, старшокласники 3 психофізичними порушеннями.

Ирина Татьянчикова, Тамара Сахно, ДВНЗ «Донбасский государственный педагогический университет», Славянск, Украина

Проблема формирования информатичных компетентностей у старшеклассников с психофизическими нарушениями

Рассматривается проблема формирования инсормационных компетентностей у старшеклассников с психофизическими нарушениями. Дается анализ современных психолого-педагогических исследований 0 целесообразности и эфффективности использования компьютерных технологий в учебно-воспитательном процессе специальных учебных заведений. Установлено, что использование информационных технологий дает возможность модернизировать и повысить качество обучения, а также интерес учащихся к овладению базовыми знаниями, что влияет на фрормирование у них инсрормационно-коммуникативных компетентностей. Обращается внимание на (C) Татьянчикова І.. Сахно Т., 2019 
коррекционную направленность использования компьютерных технологий в процессе усвоения учащимися учебного материала, поскольку этот процесс у них происходит с существенными трудностями, что обусловлено их ограниченными возможностями. Установлено, что без наличия определенных знаний в области инфрорматики таким учащимся невозможно приспособиться к жизни в обществе после окончания школы. Доказано, что состояние теоретического и практического решения обозначенной проблемы в специальной педагогике не отвечает современным запросам общества, что указывает на актуальность и востребованность поднятых вопросов. В статье обоснована необходимость определения педагогических технологий формирования информационных компетентностей у учащихся старших классов специальной общеобразовательной школы.

Ключевые слова: информационная компетентность, информационно-коммуникативные технологии, старшеклассники с психосизическими нарушениями.

Iryna Tatyanchikova, Tamara Sakhno, "Donbas state pedagogical university" Slavyansk, Ukraine Problem of formation of informatics competences for high school students with psychological disorders

The article deals with the problem of the formation of informatical competences in senior pupils with psychophysical disorders. The analysis of modern psychological and pedagogical research about the feasibility and effectiveness of the use computer technology in the educational process of special educational institutions is given. It has been established that the use of information technologies makes it possible to modernize and improve the quality of education, also the pupils' interest in mastering basic knowledge, which affects on the formation of their information and communication competencies. Attention is paid to the correctional orientation of the use computer technology in the process assimilation of educational material by pupils, because this process is taking place with considerable difficulty due to their limited capabilities. It has been established that without some knowledge in the area of informatics such students cannot adapt to life in society after graduation. It is proved that the state of theoretical and practical solutions to the identified problem in special pedagogy does not meet the contemporary needs of society, which indicates the relevance and demand of the issues raised. The article substantiates the need to determine the pedagogical technologies for the formation of informatics competencies among senior pupils of a special comprehensive school. Keywords: informatics competency, information and communication technologies, senior pupils with psychophysical disabilities.

$\mathrm{P}$ озуміння сутності і вивчення інформатичної компетентності людини в нових соціально-економічних умовах сьогодення особливо привертає увагу фахівців, оскільки вона невід'ємно пов'язана з ї практичною діяльністю. Сучасний етап розвитку суспільства характеризується широким використанням комп'ютерної техніки, нових інформаційних технологій, телекомунікацій, оновлених видів документального зв'язку. Відповідно, підвищуються вимоги до навчання, знань та умінь учнів, насамперед старшокласників, до рівня їхньої компетентності в галузі інформатики і комп'ютерної техніки, тобто їхньої інформатичної компетентності взагалі. Використання сучас-

«ОСОБЛИВА ДИТИНА: навчання і виховання», № 2, 2019 
них інформаційних технологій дає можливість модернізувати навчально-виховний процес, підвищити якість навчання, інтерес учнів до оволодіння базовими знаннями, що суттєво впливає на формування в них інформаційно-комунікаційних компетентностей.

Особливого значення набуває опанування комп'ютерних технологій учнями 3 психофізичними порушеннями, у яких цей процес відбувається зі значними труднощами, що зумовлено їхніми обмеженими можливостями. Водночас, без наявності певних знань у галузі інформатики неможливо таким учням пристосуватись до життя у суспільному просторі після закінчення школи. Ці знання потрібні у процесі освоєння професійної кваліфікації, бо майже всі сучасні завдання вирішуються за допомогою комп'ютерної техніки. Також інформатичні знання безпосередньо впливають на розв'язання питань соціалізації учнів загалом, на комфортність життєдіяльності осіб цієї категорії у нових соціальних умовах. Водночас, стан теоретичного і практичного розв'язання зазначеної проблеми у спеціальній педагогіці не задовольняє сучасні суспільні потреби, що вказує на актуальність та затребуваність порушених питань і спонукає до більш детального розгляду, насамперед, сучасних досліджень щодо подальшого визначення педагогічних технологій формування інформаційно-комунікаційних компетентностей в учнів із психофізичними порушеннями.

Отже, метою цієї статті є аналіз сучасних досліджень щодо проблеми формування інформатичних компетентностей у старшокласників із психофізичними порушеннями та обгрунтування необхідності визначення змісту й напрямів, тобто педагогічних технологій іх формування в учнів старших класів спеціальних загальних середніх навчальних закладів.

Психолого-педагогічні питання в контексті зазначеної проблеми висвітлено в роботах В. Беспалова, Г. Васьківської, І. Іванюк, Н. Ковчин, А. Савченко, О. Рутківської, Ю. Татура, А. Хуторського та ін., які наголошують, що процес формування інформатичних компетентностей у старшокласників із психофізичними порушеннями передбачає застосування ними комп'ютерних технологій, а також здатність орієнтуватися в інформаційному просторі, отримувати необхідну інформацію й оперувати нею відповідно до власних потреб і вимог сучасного високотехнологічного інформаційного суспільства.

Під інформатичною компетентністю розуміємо здатність особистості орієнтуватися в потоці інформації, уміння працювати з різними видами інформації, знаходити потрібну інформацію, класифікувати іiі, а також на основі здобутих знань вирішувати будь-яку інформаційну проблему за допомогою комп'ютера.

Варто зазначити, що педагогічні колективи спеціальних загальних середніх закладів освіти стоять біля витоків розв'язання питання: як і в якому обсязі формувати базовий рівень інформаційно-комунікаційної компетентності в учнів iз психофізичними порушеннями. Ця проблема є наслідком обговорення проек- 


\section{BEKSOP TPAHRGOPMMANUIII}

ту Концепції державного стандарту спеціальної освіти (1999р.), у якому не було підтримано ідею впровадження предмета «Основи інформатики» у підготовку учнів спеціальної школи. Підставами такого підходу до цієї дисципліни могли бути такі:

- недостатня підготовка у вищих начальних закладах майбутніх фахівців 3 комп'ютерних технологій;

- недостатня матеріально-технічна база спеціальних шкіл, зокрема, відсутність у закладах комп'ютерних класів;

- недостатня доказова база щодо можливостей набуття учнями із психофізичними порушеннями комп'ютерної грамотності, оволодіння ними відповідними технологіями, що обумовлено недостатньою обгрунтованістю цього питання у теоретичних дослідженнях, а також відсутністю певного практичного досвіду у цій галузі.

Отже, в обговоренні проекту, учителі на той час висловилися проти ідеї впровадження в практику спеціальної школи новітніх інформаційних технологій.

На сучасному етапі функціонування і розвитку системи спеціальної освіти назріла гостра необхідність щодо ідеї застосування комп'ютерних технологій у практику роботи спеціальних навчальних закладів. До цього спонукає й проведення останніх наукових досліджень у галузі спеціальної педагогіки. Автори довели доцільність і необхідність використання комп'ютерів у роботі з дітьми із психофізичними порушеннями. Результати проведених досліджень підтверджують ефективність формування інформаційно-комунікаційних компетентностей, що передусім ознайомлює таких учнів із комп'ютером; сприяє розвитку в них пізнавального інтересу до способів його практичного використання; створює оптимальне інформаційне середовище для учня, яке побудоване на ігрових технологіях; закладає базові знання, необхідні для вивчення основних предметів.

I. Холковська вважає, що у навчанні різних категорій дітей з особливими освітніми потребами, усе ширшого застосування набувають персональні комп'ютери. На їі думку, комп'ютерні засоби можна використовувати для розвитку навичок читання, письма, навчання математики, іноземної мови тощо. Комп'ютер може використовуватися також як засіб контролю за діяльністю дітей, формування різних видів самоконтролю. Досвід використання комп’ютерної техніки у спеціальному навчальному закладі свідчить про позитивні результати як у навчальній діяльності, так і в корекції багатьох психофізичних недоліків розвитку дітей [12].

Проте, науковці стверджують, що під час упровадження інформаційно-комунікаційних технологій у спеціальній школі необхідно враховувати особливості психіки дітей з порушеннями розвитку, найперше ті, що можуть ускладнити роботу з технікою. Це, зокрема, підвищена втомлюваність, розпорошена увага, сповільнений темп сприймання, тривале входження у процес роботи.

«ОСОБЛИВА ДИТИНА: навчання і виховання», № 2, 2019 
Безумовно, особливості психофізичного розвитку учнів обумовлюють й специфіку іх навчання. Перед педагогами постає безліч питань: як і в якому обсязі формувати базовий рівень компетентностей у дітей з психофізичними порушеннями; наскільки інтерес таких учнів до комп'ютера підвищує їхню працездатність, сприяє зосередженню уваги і збільшує темп роботи. Ці питання визначають напрями подальших наукових напрацювань у спеціальній педагогіці.

Різні аспекти науково-педагогічної проблеми інформатизації та комп'ютеризації навчального процесу спеціальних шкіл висвітлено у працях Н. Глазкової, В. Засенка, А. Колупаєвої, О. Кутепової, О. Легкого, С. Миронової, Б. Мороза, Ю. Сакуліної, С. Трикоз та ін. При цьому науковці виділяють два напрями:

- можливість використання комп'ютера як засобу навчання;

- доцільність і особливості використання технологій навчання учнів із психофізичними порушеннями основам комп'ютерної грамотності.

Результати проведених досліджень засвідчують, що комп'ютерні технології розширюють можливості учнів спеціальної школи, оскільки стимулюють їхню пізнавальну активність, посилюють мотивацію до навчання, сприяють максимальній індивідуалізації цього процесу, оптимізують управління навчальною діяльністю. Отже, можна стверджувати, що використання комп'ютерних технологій має потужний корекційний потенціал, вміле застосування якого в навчальновиховному процесі спеціальних загальноосвітніх шкіл сприятиме більш успішній соціалізації учнів із психофізичними порушеннями $[1,8]$.

Так, О. Легкий, який досліджував можливості використання комп'ютера під час викладання предметів природничо-математичного циклу у різних типах навчальних закладів, констатує, що така робота учнів може супроводжуватися «негативним ефектом і за результатами, і за психофізіологічним станом» через неготовність дітей сприймати інформацію в незвичному для них вигляді та невмінням користуватися новим для них технічним засобом [5]. Утім, автор стверджує, що розроблення стандарту вивчення інформатики для учнів із психофізичними порушеннями у системі державного освітнього стандарту для спеціальних шкіл $€$ можливим i правомірним. Проте, проводити уроки інформатики О. Легкий пропонує лише на завершальних етапах навчання для тих, хто виявляє схильність та інтерес до опанування професій оператора комп'ютерного набору. Використовувати ж комп'ютери, як технічні засоби навчання у спеціальних школах, на думку автора, доцільно на всіх ступенях неперервної освіти.

О. Кутепова, яка досліджувала можливості використання комп'ютера в процесі навчання учнів спеціальної школи, дійшла висновку, що учні старших класів можуть бути користувачами персонального комп'ютера. Автор підкреслює, що мінімальний рівень підготовки до роботи на комп'ютері (навички роботи 3 клавіатурою, мишею, монітором) у старшокласників із психофізич- 


\section{BEKSOP TPAHROCOPMANUIII}

ними порушеннями виявлено ще до початку експерименту. При цьому діти розповідали про свій досвід «спілкування» 3 комп'ютером та намагалися поділитися знаннями один з одним. Отже, нові реалії життя, що характеризуються загальною інформатизацією та комп'ютеризацією суспільства, сприяють і формуванню в учнів зазначеної категорії пізнавального інтересу до нетрадиційних для них джерел інформації. Формування, розширення та закріплення в учнів спеціальної школи користувальних умінь і навичок, на думку О. Кутепової, може відбуватися під час вивчення будь-яких предметів, де передбачена робота з комп'ютером [4].

Н. Глазкова мету навчання основ інформатики учнів бачить у формуванні в них таких інформаційних знань і умінь, які є доступними та необхідними для життя в сучасному інформаційному суспільстві, а також для розуміння перетворень, які в цьому суспільстві відбуваються [1].

Ю. Сакуліна зазначає, що введення елементів комп'ютерної грамоти в навчальний процес сприяє підвищенню ефективності соціалізації учнів спеціальної школи, оскільки сам процес їхної взаємодії з комп'ютером, знайомство 3 його можливостями та шляхами використання для задоволення пізнавальних потреб, розширює світогляд дітей, розвиває іх мислення, пам'ять, увагу, а також цілеспрямованість і самостійність. Авторка зауважує, що засвоєння дітьми 3 психофізичними порушеннями елементів комп'ютерної грамотності та опанування ними умінь і навичок користувача може здійснюватися на окремих уроках із різними програмними засобами у межах затвердженого школою навчального плану. Водночас, не заперечується й можливість введення уроків інформатики, утім, це потрібно робити лише у старших класах [9].

Варто зазначити, що аналіз змісту першоджерел щодо освітніх компетенцій дає підстави констатувати, що інформаційно-технологічна грамотність є однією 3 ключових компетенцій (П. Беспалов, В. Введенський, О. Дахін, О. Іванова, В. Ледньов, А. Маркова, О. Пометун, М. Рижаков, Г. Селевко, В. Сластьонін, Н. Тализіна, А. Хуторський та ін.).

Це знаходить своє підтвердження у дослідженні С. Миронової, яка доводить, що комп'ютер має бути не об’єктом вивчення, а засобом, за допомогою якого дитина з порушеннями психофізичного розвитку зможе заповнити прогалини у знаннях із різних предметів. Вдало дібрані комп'ютерні програми забезпечують розвиток здібностей, умінь, інтересів та навичок дитини і потребують певного рівня пізнавальної активності [6].

Під час роботи на клавіатурі розвивається дрібна моторика. Комп'ютер може стати потужним джерелом формування не лише пізнавальної активності, а й прагнення до знань, отримання задоволення результатами власної діяльності, розвитку самостійності мислення. Завдяки використанню комп'ютерної техніки здійснюється індивідуалізація навчання, орієнтація на конкретного учня [8].

«ОСОБЛИВА ДИТИНА: навчання і виховання», № 2, 2019 91 
Утім, у більшості вищезазначених досліджень акцентовано увагу на тому, що правильно побудована стратегія набуття інформатичної компетентності не повинна зводитися до простого переліку тих знань і умінь, якими учні мають оволодіти (знання пристрою комп'ютера, навички роботи з текстовим редактором, уміння шукати і знаходити потрібну інформацію в Інтернеті тощо), хоча такі знання та вміння дійсно важливі для старшокласників спеціальної школи. Між тим, автори стверджують, що традиційний шлях навчання не забезпечує успішного перенесення навичок з однієї ситуації в іншу. Учні опановують окремі прийоми роботи на комп'ютері, але у них не виникає розуміння, як ці прийоми мають поєднуватися між собою для розв'язання різноманітних практичних завдань. Справжнє володіння комп'ютером передбачає більш спрямоване, творче і гнучке використання цього потужного інструменту. Учень повинен добре уявляти собі кінцеву мету, розуміти, як за допомогою комп'ютера можна вирішити різні завдання, і вміти реально використовувати основні технічні пристрої й можливості комп'ютера. Кожна окрема навичка роботи на комп'ютері, спрямована на розв'язання практичних завдань, набуває для учнів із психофізичними порушеннями зовсім інший особистий сенс.

Лише тоді правомірно говорити про справжню комп'ютерну грамотність учня, а отже і про його інформатичну компетентність, коли виникає розуміння: сучасні технічні засоби можуть перетворитися на інструмент отримання нових знань, що знадобиться й у подальшому житті.

Висновки. Формування інформатичної компетентності засобами комп'ютерних технологій сприяе всебічному розвитку старшокласників із психофізичними порушеннями. Інформаційно-комунікаційні технології можуть стати потужним джерелом прагнення учнів до знань, отримання ними задоволення результатами власної діяльності, розвитку самостійності мислення, а також появі пізнавальної активності. Завдяки використанню комп'ютерної техніки здійснюється індивідуалізація навчання, відбувається орієнтація на конкретного учня, набуваються навички користування комп'ютерними технологіями у самостійному житті, що суттєво впливає на подальшу соціалізацію кожного з них.

Перспективи наступних досліджень полягають у визначенні основних напрямів, змісту і методики формування інформаційно-комунікаційних компетентностей в учнів із психофізичними порушеннями, розробленні нових концептуальних положень щодо оптимізації цього процесу.

\section{ЛITEPATУPA}

1. Глазкова Н. Н. Обучение элементам информатики старших школьников с недоразвитием интеллекта: автореф. дис. канд. пед. наук: 13.00.03 / Н. Н. Глазкова // Российск. гос. пед. ун-т им. А. И. Герцена. - СПб., 2007. - 22с. 
2. Запорожченко Ю. Г. Використання засобів ІКТ для підвищення якості інклюзивної освіти: Інформаційні технології в освіті / Ю. Г. Запорожченко. - Херсон: ХДУ, 2013. - № 15. C. $138-145$.

3. Засенко В. В., Колупаєва А. А., Мороз Б. С., Овсяник В. П. Використання інформаційних технологій в умовах спеціального та інклюзивного навчання дітей зі слухомовленнєвими порушеннями / В. В. Засенко, А. А. Колупаєва , Б. С. Мороз, В. П. Овсяник. - URL: http:// rc-vabos.at/_1d/0/9/.

4. Кутепова E. Н. Совершенствование процесса обучения умственно отсталых учащихся с применением программно-методических средств: дис. канд. пед. наук. - СПб., 2002. - 183 с.

5. Легкий О. М. Організаційно-педагогічні умови використання комп'ютера у спеціальній школі: автореф. дис. канд. пед. наук: 13.00.03/ О. М. Легкий // Ін-т дефектології АПН України. - К., 2001. -16 c.

6. Миронова С. Використання комп'ютера у корекційному навчанні дітей з вадами інтелекту / С. Миронова // Дефектологія. - 2003. - № 3. - С. 41 - 45.

7. Наукові підходи до навчання комп'ютерної грамоти розумово відсталих дітей. - [Електронний ресурс]. - Режим доступу: http://www.vmurol.com.ua/upload/Naukovo_doslidna\%20 robota/Elektronni_vidannya/Act_problemi/2010/31.pdf. - 2010.

8. Савінова $\bar{H}$. B. Інформаційно-комунікаційні технології в корекційній освіті/ Н. В. Савінов. - [Електронний ресурс]. - Режим доступу: http://enpuir.npu.edu.ua/ bitstream/123456789/12013/1/Prikhodko.pdf. - 2015.

9. Сакулина Ю. В. Повышение эффективности уроков трудового обучения в специальной (коррекционной) школе VIII вида на основе использования информационных технологий: автореф. дис. канд. пед. наук: 13.00.03/Уральск, гос. пед. ун-т. - Екатеринбург, 2007. - 24 с.

10.Татьянчикова I., Сахно Т. Формування інформаційно-комунікаційних компетентностей в учнів на уроках інформатики / I. Татьянчикова, Т. Сахно // Цифрова компетентність сучасного вчителя нової української школи: зб. тез доповідей учасників Всеукр. наук.-практ. семінару (Київ, 12 березня 2019p.) / За заг. ред. О. В. Овчарук. - К.: Інститут інформаційних технологій і засобів навчання НАПН України: К., 2019. - С. 91- 94.

11. Трикоз $C$. Використання комп'ютерних технологій у навчанні дітей з порушеннями інтелектуального розвитку / С. Трикоз // Цифрова компетентність сучасного вчителя нової української школи: зб. тез доповідей учасників Всеукр. наук.-практ. семінару (Київ, 12 березня 2019p.) / За заг. ред. О. В. Овчарук. - К.: Інститут інформаційних технологій і засобів навчання НАПН України: К., 2019. - С. 99 - 100.

12. Холковська I. Л. Корекційна педагогіка / І. Л. Холковська. - Вінниця: ВДПУ ім. М. Коцюбинського, 2007. -328 с.

\section{REFERENCES (TRANSLATED AND TRANSLITERATED)}

1. Hlazkova, N. N. (2007). Obuchenie elementam informatiki starshikh shkolnikov s nedorazvitiem intellekta [Education elements of computer science of senior pupils with intellectual disabilities]. Extended abstract of candidate's thesis. Saint Petersburg [in Russian].

2. Zaporozhchenko, Yu. H. (2013). Vykorystannia zasobiv IKT dlia pidvyshchennia yakosti inkliuzyvnoi osvity. [The use of ICT tools to improve the quality of inclusive education:]. Informatsiini tekhnolohii v osviti - Information technology in education, 15, 138-145 [in Ukrainian]. 
3. Zasenko, V. V., \& Kolupayeva, A. A., \& $\mathcal{F}$ Moroz, B. S., \& Ovsyanyk, V. P. (n.d.). Vykorystannia informatsiinykh tekhnolohii $\mathrm{v}$ umovakh spetsialnoho ta inkliuzyvnoho navchannia ditei zi slukhomovlennievymy porushenniamy [The use of information technology in the context of special and inclusive education of hearing-impaired children]. http://rc-vabos.at. Retrieved from http:// rc-vabos.at/_1d/0/9/[in Ukrainian].

4. Kutiepova, Ye. N. (2002). Sovershenstvovanie protsessa obuchenyia umstvenno otstalikh uchashchykhsia s primeneniem prohrammno-metodicheskikh sredstv [Improving the learning process of mentally retarded pupils with using software tools]. Candidate's thesis. Saint Petersburg [in Russian].

5. Lehkii, O. M. (2001). Orhanizatsiino-pedahohichni umovy vykorystannia kompiutera $\mathrm{u}$ spetsialnii shkoli [Organizational and pedagogical conditions of using a computer in a special school]. Extended abstract of candidate's thesis.- Kiev [in Ukrainian].

6. Mironoza, S. (2003). Vykorystannia kompiutera u korektsiinomu navchanni ditei z vadamy intelektu [Use of computer in correctional education of children with intellectual disabilities]. Defectology - Defektolohiya, 3, 41-45 [in Ukrainian].

7. Naukovi pidkhodi do navchannia kompiuternoi hramoti rozumovo vidstalikh ditei [Scientific approaches to computer literacy training for mentally retarded children]. (2010). http://wrewe. vmurol.com.ua. Retrieved from http://www.vmurol.com.ua/upload/Naukovo_doslidna\%20 robota/Elektronni_vidannya/Act_problemi/2010/31.pdf [in Ukrainian].

8. Savinova, N. V. (2015). Informatsiyno-komunikatsiyni tekhnolohiyi v korektsiyniy osviti [Information and communication technologies in correctional education]. http://enpuir.npu.edu. ua. Retrieved from http://enpuir.npu.edu.ua/ bitstream/123456789/12013/1/Prikhodko.pdf [in Ukrainian].

9. Sakulina, Yu. V. (2007). Povishenie effektivnosti urokov trudovoho obucheniia v spetsialnoy (korrektsionnoy) shkole VIII vida na osnove ispolzovaniia informatsionnikh tekhnolohii [Improving the efficiency of employment lessons in a special (correctional) school of VIII type based on the use of information technology]. Extended abstract of candidate's thesis. Ekaterinburh [in Russian].

10. Tatianchikova, I., E S Sakhno, T. (2019). Formuvannya informatsiyno-komunikatsiynykh kompetentnostey v uchniv na urokakh informatyky [Formation of information and communication competencies in pupils at computer science classes]. Tsifrova kompetentnist suchasnoho vchitelia novoi ukrainskoi shkoli: zb. tez dopovidei uchasnikiv Vseukr. nauk.-prakt. Seminaru (12 bereznia 2019 roku) - Digital competence of the modern teacher for the new Ukrainian school. (pp. 91 - 94). Kiev: Institut informatsiinikh tekhnolohii i zasobiv navchannia NAPN Ukraini [in Ukrainian].

11. Trikoz, S. (2019). Vikoristannia kompiuternikh tekhnolohii u navchanni ditei z porushenniami intelektualnoho rozvitku [Use of computer technologies in teaching children with intellectual disabilities]. Tsifrova kompetentnist suchasnoho vchitelia novoi ukrainskoi shkoli: zb. tez dopovidei uchasnikiv Vseukr. nauk.-prakt. Seminaru (12 bereznia 2019 roku) - Digital competence of the modern teacher for the new Ukrainian school. (pp. 99 - 100). Kiev: Institut informatsiinikh tekhnolohii i zasobiv navchannia NAPN Ukraini [in Ukrainian].

12. Kholkovska, I. L. (2007). Korektsiyna pedahohika [Correctional pedagogy]. Vinnitsia: VDPU im. M. Kotsubinskoho [in Ukrainian]. 